\title{
Getting Out of Poverty in Uganda through Education in Agriculture
}

\author{
W. F. Epeju
}

\begin{abstract}
This is a paper review of work presented at two different forums at Makerere University. One was the Conference on school agriculture in Uganda organized by the Department of Agricultural Extension Education and Innovation Studies. The same paper was shared with stakeholders of Uganda Agribusiness Council on a different day in a Workshop on Agricultural education, Agrifood systems and Youth unemployment in Uganda. Using library research \& reflection with excerpts from fieldwork, document and content analysis, data were generated for the paper. Uganda's economy is reliant on agriculture which has a low agricultural productivity demonstrating some inabilities in poverty reduction. The majority of the farmers are smallholder farmers engaging mostly women labour. Food and nutrition security are not assured. The agricultural commodities for exports are not so competitive because of the low agricultural value chain with little value addition. The country is sliding into being a net importer of food despite having a huge potential for agriculture and the natural resources possessed. A green revolution is necessary with relevant research and value addition of agricultural commodities supported by better infrastructure, and markets which are all dependent on better education \& trained human resource to improve the country's economy.
\end{abstract}

Index Terms-Agriculture, Economy, Education in Agriculture, Poverty.

\section{INTRODUCTION}

Agriculture is the source of food, raw materials for industries, employment, domestic income, foreign exchange, national defense and also attracts some form of recreation (tourism) in many developing countries [1]. Globally, the area of land available is about 57, 900, 000 sq. miles $(148,224,000$ sq. $\mathrm{km})$ that will still carry a global population of $8,177,100,000$ by 2025 [2]. There are over 500 million smallholder farms globally, each of which may be about 2 ha in size [3]. The continent of Africa covers the area of $11,700,000$ sq. miles $(29,952,000$ sq.km) and will have a population of 1, 642,900,000 (1.62 billion) by 2025 [4]. Africa is an extremely rich continent with an enormous development potential. However, only talking about that potential could not feed today's population of 1.1 billion people and which, according to UN statistics, is expected to increase to 2.4 billion by 2050 . Food production needs to increase by sixty percent in the next fifteen years or so to cope with demand [5]. Nonetheless, there are still huge areas of arable land in Africa, south of Sahara. About 200 million hectares (ha) or almost half of the world's land reserve for agriculture is available on the continent. Even more

Published on March 06, 2020

W. F. Epeju is with Kyambogo University, Kyambogo, Uganda. (e-mail:wepeju@yahoo.co.uk) important are the possibilities for more effective and more sustainable use of the land already cultivated. About seventy percent of today's job opportunities are, as mentioned earlier, found in the rural areas. African agriculture is at least fifty percent managed by female farmers [6]. There are about 33 million farms with an area of less than 2 ha each. This is underutilization of the agricultural potential. The average age of African farmers is today very high (an average of 60 years), but at the same time sixty percent of Africans are less than 24 years of age thus are youth. The number of young Africans that every year could enter the labour market is enormous and was by 2015 estimated to be 330 million. Against that background, it is easy to understand why a number of young Africans try to leave for say Europe to seek new opportunities. Shall that trend be changed? The African agriculture must, no doubt, be developed to give hope for the future, even if not all young Africans will see a role of their own in that field as also has been the case in Europe [7]. Uganda in East Africa is one of those African countries with a huge potential in agriculture.

\section{Methodology}

The paper is a review of what was presented to a conference on school agriculture in Uganda organized by Department of Agricultural Extension and Innovation Studies of Makerere University held at Grand Global Hotel, Kikoni, Kampala, Uganda. The paper also at a different workshop addressed the stakeholders of the Uganda Agribusiness Council on the topic of Agricultural Education, Agrifood Systems and Youth Unemployment in Uganda on March 18, 2019 at Makerere University, Senior Common, Kampala. Library research and reflection with some excerpts from fieldwork were prior done at Kyambogo University in Uganda. Document and content analysis were done. Themes and subcategories were used for analysis through open and axial coding. The subheadings used in the presentation emanated from the analysis on documents and content encountered during the literature review and reflection.

\section{Uganda's AgRicultural Resources}

Arable land suitable for agriculture in Uganda is estimated to be eighty percent of 197,000 sq.km of the total land area available [8]. In addition, there are forestry and water resources for use in agriculture with favourable weather although climate change effects are now experienced. Forty percent of the land is currently estimated to be under cultivation. With a population of forty-two million, increasing at the rate of three point two percent 
$(3.2 \%)$ annually, the country has to provide food, income and improved welfare for the people, seventy percent of whom are the youth. Ninety percent of the population lives in the rural area where they work in agriculture. Ninety-four percent of the agricultural output comes from over three million smallholder farmers, each living on less than two hectares ( $2 \mathrm{ha}$ ) of land except for the commercial sugar cane and tea estates. Production is characterized by use of simple tools and family labour. For the area under cultivation: banana growing takes thirty percent of the cultivated land; cereals cover about twenty-five percent; root crops, pulses, oilseeds take twenty percent; industrial crops such as coffee, tea, tobacco take twenty-five percent of the cultivated land. The farm management systems are categories of subsistence farms; smallholder coffee farms; out growers of tea/sugar cane; estate farms; traditional semi-nomadic pastoralism (livestock keepers); and modern dairy farms. Export commodities are increasingly more diversified but dominated by coffee, cotton, tea, and fruits. Nonetheless, foreign exchange earnings from agriculture alone for the lack of competitiveness of agricultural commodities are unable to square up the country's import bill.

\section{A. Agriculture in Uganda}

From shadoof irrigation used in early civilizations $(6,000$ B.C.) to modern sprinkler irrigation used by Madhivani Kakira Sugar estate farm (Uganda), agriculture in Uganda has undergone many changes over the last 120 years. The Department of Agriculture opened in 1898 at Entebbe [9], [10]. The emphasis then was the development of crops to be exported to the home-countries of colonizers but today agriculture has become so diverse and production more knowledge based for its success requiring high quality education and trained human resource. No wonder, schools got drawn in to do more to benefit the majority of people in the country employed in it. Uganda is well endowed with favourable climate and good soils suitable for agriculture, conditions which continue to interest schools and governance in order to enable the majority of the citizens to get out of poverty. Uganda has a comparative advantage in agriculture but weak on the export of competitive agricultural commodities.

\section{B. Poverty status in Uganda}

One of the common ills of Ugandan communities continues to be poverty against availability of a good potential in agriculture. Poverty has been reducing from thirty percent to less than twenty percent of population in abject poverty, which is a condition of having less than one US dollar a day. It is currently estimated to be eight point four percent $(8.4 \%)$ of the population annually is sliding back to abject poverty during the past few years. Poverty directly affects agricultural productivity (output) thus food security, income and improved welfare. Other ills also known in the Ugandan communities include ignorance (illiteracy, lack of adequate knowledge and skills, poor attitudes and values); disease (human diseases, crop diseases, animal diseases); squalor (unclean conditions of living); corruption (high corruption index); environmental degradation (climatic change effects such as protracted droughts, floods: crop failure, animal losses, famine). These are known country wide. Therefore, causes of poverty often include crop failure; pests \& diseases of crops, livestock and human beings leading to losses; losses through drought, floods, and natural disasters (earthquakes, landslides); war; landlessness; low commodity prices; poor economic conditions (unproductive manpower because of poor quality education and inadequate training, shortage of manpower, no markets, poor infrastructure); and incapacitating personal and environmental conditions. Ways to alleviate poverty towards its eradication include: promoting agricultural growth (wealth creation through mainly agriculture); land reform for higher productivity; increased access to improved inputs, lucrative markets, and enabling services; credit for investment in production so as to improve farming for higher output; use of appropriate technology; additional employment to get extra income (jobs in non-farm sector, reasonable transfers to the poor for better welfare); good producer prices; making food affordable or cheaper; expanding market for farm produce; reduction of costs for inputs (producer goods); and sensitization and mobilization through educational empowerment [11].

\section{UGANDA's EDUCATION SYSTEM}

Since 1962, Uganda's year of Independence, there have been more deliberate attempts to stimulate the education system to take on teaching knowledge and skills for economic growth and better technology development especially in agriculture from the primary schools especially from Primary 4 (Grade Four) to university. It was hoped that would help address some inadequacies among the farming populace from the school going and ultimately through extension services to increase agricultural productivity towards industrialization. School gardens and school farms proved to be useful in that regard. In the year 2000, a clear syllabus for primary school agriculture was launched to reinforce the general secondary school agriculture syllabus which had existed and used in various forms since 1970. Primary school agriculture was no longer a part of another subject such as science but taught on its own. Table I shows the outline of the content offered in education systems in which the teaching of agriculture happens. Successful teaching of agriculture calls for the following requirements stipulated: "Adequate financial support; adequate resources such as time, trained and motivated teachers, land, tools and equipment; appropriate teaching and learning methods; rural transformation enlisting voluntary participation in development by communities; reduced migration of labour; assessment and evaluation approaches to allow equality and access to quality education for development; and effective management of instruction for quality assurance."

The offer of agriculture especially in primary and secondary schools is in three forms [12]. It was a cocurricular activity or a separate school subject or a part of another subject (usually science). Implementation meets different challenges such as negative attitudes, poor weather, poor access to markets, low input supply, lack of capital, labour bottlenecks, poor transport, land conflicts/poor land management, pests \& diseases (human, crop and livestock), poor planning and corruption. Without a clear evaluation of the impact of teaching agriculture in schools on agricultural productivity and on the economy, the high drive it received 
at the launch has not been sustained.

\section{A. Education in agriculture}

Globally, schools exist to prepare those who register in them so that they can become effective servants, develop good character; learn to be humble, obedient, orderly and loyal to authority. In short, the word SCHOOL becomes the acronym for those desirable attributes in a person namely good servant, humbleness, good character, obedience, orderliness and loyalty. All societies in the world through their educational systems, whether informal, formal or nonformal, train their citizens to attain high standards of those qualities for peaceful living and modern knowledge based production for economic progress. Through schools, human beings grow and develop thus get educated. Through colonization, Christian missionaries who came to Uganda from 1877 brought the idea of schools, modern education and industrialization. That led to the creation of the Department of Education in 1896 which introduced new ways of nurturing human growth and development for the betterment of society [13], [14]. Between 1896 to date, many education committees and commissions have operated to ensure the best from school efforts are benefited.

Uganda and humanity merit to get out of poverty and enjoy better modern living especially from agriculture and the natural resources Uganda possesses. Under Arthur Bagunywa, a prominent educationist, the National
Curriculum Development Centre was opened in 1972 to ensure that the schools conducted appropriate curricula for teaching and learning important for nation building in Uganda. Such efforts culminated in the setting up of the Education Policy Review Commission (EPRC) headed by a very prominent Professor of Education, the late Professor William Senteza Kajubi [15]. The White Paper on education 1992 from Kajubi's report continues to direct the principles and practice of education in Uganda today till another holistic review on education is done. Consequently, today in Uganda, agriculture is one of those subjects taught from primary schools through secondary schools and several tertiary institutions to universities. The current debate in Uganda is on what type of education is best in order to move economic development faster during the twenty first century especially through agriculture and get out of poverty. There is public dissatisfaction on the current quality of education associated with enormous problems of unemployment. Against that background, it is easy to understand why a number of young Ugandans try to leave for say Europe, USA and Middle East countries to seek new and better opportunities. Shall that trend be changed? Education and training in agriculture has been mooted for long as a possible strategy as agriculture is the basis for economic and technology development.

TABLE I: OUTLINES OF WHAT IS TAUGHT IN UGANDAN SCHOOLS AS STIPULATED BY THE NATIONAL CURRICULUM DEVELOPMENT CENTRE (UGANDA'S MINISTRY OF EDUCATION AND SPORTS 2019)

\begin{tabular}{|c|c|c|c|c|}
\hline $\begin{array}{l}\text { NURSERY } \\
3 \text { to } 5 \text { yr olds } \\
\text { Duration } 3 y r s\end{array}$ & $\begin{array}{l}\text { PRIMARY } \\
6 \text { to } 12 \text { yr olds } \\
\text { Duration } 7 \text { yrs }\end{array}$ & $\begin{array}{l}\text { GENERAL SECONDARY } \\
\text { SCHOOLS } 13 \text { to } 17 \mathrm{yr} \text { olds } \\
\text { Duration } 6 \mathrm{yrs}\end{array}$ & $\begin{array}{l}\text { VOCATIONAL } \\
\text { SECONDARY } \\
13 \text { to } 18 \text { yr olds } \\
\text { Duration } 2 \text { yrs } \\
\end{array}$ & $\begin{array}{l}\text { POST-SECONDARY } \\
+17 \mathrm{yr} \text { olds } \\
\text { Duration } 2 \text { to } 7 \mathrm{yrs}\end{array}$ \\
\hline $\begin{array}{l}\text { Subjects } \\
\text {-Sharing } \\
\text {-Playing } \\
\text {-Knowing people } \\
\text { around } \\
\text {-Singing } \\
\text {-Language } \\
\text { Development } \\
\text {-Mathematical } \\
\text { concepts } \\
\text {-Special skills } \\
\text {-General behaviour }\end{array}$ & $\begin{array}{l}\text { Subjects } \\
\text {-Reading } \\
\text {-Writing } \\
\text {-Arithmetic } \\
\text {-Art/Drawing } \\
\text { - Area } \\
\text { language } \\
\text {-English } \\
\text {-Social } \\
\text { studies } \\
\text {-Mathematics } \\
\text {-Science }\end{array}$ & $\begin{array}{l}\text { Compulsory subjects S1-S2>S4>S6 } \\
\text {-English } \\
\text {-Mathematics } \\
\text { - History/Political Education } \\
\text {-Physics } \\
\text {-Biology } \\
=\text { Chemistry } \\
\text {-Physical Education } \\
\text {-Religious Education } \\
\text {-Entrepreneurship } \\
\text {-Kiswahili }\end{array}$ & $\begin{array}{l}\text {-Technical schools } \\
\text {-Commercial Schools } \\
\text {-Business Schools } \\
\text {-Farm Schools } \\
\text {-Home Economics } \\
\text { Schools } \\
\text {-Technical Institutes }\end{array}$ & $\begin{array}{l}\text {-Technical Institutes/Colleges } \\
\text {-Business Institutes/Colleges } \\
\text {-Agricultural colleges/ Fisheries } \\
\text { Institutes/Veterinary Institutes } \\
\text {-Forestry Colleges } \\
\text { Catering Institutes } \\
\text { - Tourism/Wildlife Instituttes } \\
\text {-National Teachers Colleges } \\
\text {-Universities }\end{array}$ \\
\hline & & $\begin{array}{l}\text { Elective subjects: S3-S4 } \\
\text {-Agriculture } \\
\text {-ICT } \\
\text {-One Foreign Language (Fre, Ger,Lat, } \\
\text { Arb,Chn). } \\
\text { - Local Language } \\
\text {-Literature in English } \\
\text {-Art \& Design } \\
\text {-Performing Arts } \\
\text {-Technology \& Design } \\
\text {-Nutrition \& Food Technology }\end{array}$ & & \\
\hline
\end{tabular}

Note (NB):

1. Table I gives an outline of what the Ugandan education system offers as stipulated by the National Curriculum Development Centre supervised by Uganda's Ministry of Education and Sports

2. Duration is given for each level of education which ultimately gives a total range of 20 to 27 years to complete. The age limit for each level is given with subjects offered in combinations approved by the
Ministry of Education and Sports with its examining bodies.

\section{B. Teaching agriculture in schools}

Lessons for Uganda's efforts to teach agriculture at any level came from developed countries especially United States, Europe and Japan. At independence in 1962, Uganda as a country encountered challenges regarding the way forward in education and agricultural development. No doubt, visits to other countries provided worthwhile 
experiences. In USA, the Smith-Hughes Act after World War I was " AN ACT to provide the promotion of vocational education; to provide for cooperation with the States in the promotion of such education in agriculture and the trades and industries; to provide for cooperation with the States in the preparation of teachers of vocational subjects; and to appropriate money and regulate its expenditure" In the years that followed "The Future Farmers of America Foundation Incorporated was launched with the purpose to strengthen confidence in the farm boys and young men in themselves and their work, to encourage members in the development of individual farming programs and to promote their establishment in farming through scholarship, providing prizes and awards and assisting financially" [16]. This was the spirit in many countries in Europe and Japan to improve their economies. No wonder, in times of food insecurity globally, one sees today, yellow maize meal flowing to the needy countries from the United States of America to those countries in need.

Globally, the aims for teaching agriculture in schools are similar. They focus on manpower development for services in the agricultural sector, preservation of natural resources, increasing agricultural productivity for food security and income assuring active economies [17], [18]. In broader educational terms, the framework of quality assurance enables these aims to be achieved well at levels of educational practice. Several legal provisions and policies stipulate what needs to be done by schools to provide quality education [19], [20], [21]. Mills put it that for schools to provide quality education, they ought to assure: knowledge needed by learners; ability to think rationally; practical skills; moral character; and better individual and communal life through solving problems to meet needs [22]. Consequently, there is a relationship between education and productivity thus poverty reduction which implies that more educational achievement results in higher levels of productivity of an economy thus a way out of poverty. Primary, secondary, tertiary and university levels of education have their different impacts on an economy. In agriculture, research focuses on twelve years of basic education (primary and secondary) as formative years which determine performance of future successful farmers other factors remaining favorable. Higher education is seen important in quality research in university teaching [23].

\section{Agriculture in Ugandan schools and institutions}

Between 1896 and 2019 (123 years of modern education), the numbers of schools and institutions have grown greatly. In 2013, Uganda was reported to have over 18,000 primary schools, over 5,000 secondary schools, over 500 tertiary institutions and 32 universities [24]. Today, these numbers are reading higher. Primary (for Primary Leaving Education, PLE) and secondary (for Uganda Certificate of Education, UCE \& Uganda Advanced Certificate Education, UACE) thus schools offering agriculture ought to be in thousands. Several tertiary institutions and universities also offer agriculture. There are approved syllabuses (primary, secondary, tertiary institutions and universities) to use for schools that offer agriculture at all levels in the country. Supervision of instruction is done by agencies of the Ministries of Education and Agriculture; and the National
Council of Higher Education (NHCE) for institutions under its jurisdiction. The impacts of these great efforts in our schools to our economy remain unknown and so ought to be determined for sustainability and economic improvement.

In his comprehensive review of Uganda's education in 1989, Professor Kajubi concluded that quality teacher education is the key to success of teaching and learning in schools and institutions. The words of the EPRC commission (1989) were: "There is no system of education better than the quality of its teachers. The quality of education of any country depends to a large extent on the quality of its teachers. No education systems can succeed without adequately trained and motivated teachers. Teachers play a key role in proper implementation of various education policies and programs."

Trained teachers of agriculture in Uganda today may be over 2000, trained mainly from Makerere University, Kyambogo University, and the National Teachers' Colleges (NTCs). Whether they are well motivated remains unknown and so require a study alongside the impact of their work on the economy. The entire agricultural education arrangements in Uganda require regular evaluation and better monitoring. Secondary school candidates (UCE) in 2016 for agriculture were 203,995 ( $69 \%$ of the candidates who sat) taught by the teachers who are examination oriented, not well facilitated and poorly motivated. Greater numbers of candidates also graduate from other institutions every year. Fifty years ago when serious plans were being considered to teach agriculture in our schools it was an uphill task to start and there was no clear policy although there was some support and good will. That was the time the World Bank (IDA) came to support the cause. Things started to materialize under that support with so many challenges. Teacher training in agriculture for secondary school teaching additional to Makerere's small output, kicked off in 1972 at National Teachers College, Kyambogo [25]. Since 2007 at Kyambogo University through the assistance of the Norwegian Government, the country has been reinforcing the training of vocational teachers including teachers of agriculture by upgrading the vocational pedagogy needed by the teachers through two programmes namely: Postgraduate Diploma in Vocational Pedagogy (PGDVP) and Master's in Vocational Pedagogy (MVP). The output from the two programmes remains small. Other programmes are there alongside to help meet the country's need for quality teachers of agriculture.

In 2004, the National Agricultural Education Policy (NAEP) was enacted by the Republic of Uganda with a vision to promote quality formal and non-formal agricultural education and training to be accessible to all by 2017. This situation of access calls for an evaluation as 2017 expired. Mwanga-Waiswa identified some achievements and constraints in the implementation of NAEP in selected educational institutions that offer agriculture in Uganda [26]. He found that the teaching in institutions was more skills oriented; the preparation of students for the field was more competence-based; more practical work was done on demonstration gardens and institutional farms; students were more motivated through rewards introduced and began to view agriculture as a business activity for a living. The constraints that the educational institutions met were: 
inadequate funds for acquiring modern training equipment; lack of modern infrastructure such as laboratories, ICT facilities, demonstration plots and farms; lack of well qualified teaching staff and poor staff remuneration; a declining interest in agriculture by the general population because of high costs of production and unpredictable harsh weather conditions; and inadequate monitoring/supervision by the pertinent national authorities in education and agriculture. The recommendations were: to seek more funding; do more monitoring and evaluation of agricultural education and training.

\section{Sustainability of Agricultural EduCATION AND TRAINING PROGRAMMES IN UGANDA}

Agriculture in schools and institutions will depend largely on continued policy and financial support with good will which has to open a clear way for effective implementation and results. Public-private partnerships will need to have a clear way to come in. Table II shows numbers of the educational institutions that offer the agriculture subject and its disciplines in Uganda.

TABLE II: NUMBER OF EDUCATIONAL INSTITUTIONS THAT OFFER AGRICULTURE IN UGANDA 2018

\begin{tabular}{|c|c|c|c|}
\hline LEVEL & $\begin{array}{l}\text { COUNTRY } \\
\text { TOTAL NO. } \\
\end{array}$ & $\begin{array}{l}\text { OFFERING } \\
\text { AGRICULTURE }\end{array}$ & $\begin{array}{l}\% \text { OFFERING } \\
\text { AGRICULTRE }\end{array}$ \\
\hline PRIMARY & 22,000 & 22,000 & $100 \%$ \\
\hline SECONDARY & 5,843 & $\begin{array}{l}\text { 2,082 'O’L; } 253 \\
\text { 'A'L }\end{array}$ & $\begin{array}{l}36 \% \text { 'O’L; 4\% } \\
\text { 'A'L }\end{array}$ \\
\hline NTCs & 05 & 05 & $100 \%$ \\
\hline UNIVERSITIES & 48 & 12 & $25 \%$ \\
\hline
\end{tabular}

Source: Mulumba supplied these figures from records of NCDC [27]
Table II shows an expansion in the number of educational institutions nationally and those offering agriculture under the direction of Ministry of Education and Sports 2018. There are also private institutions that teach agriculture that are not captured in Table II. Note: 'O' $\mathrm{L}$ is Ordinary Level \& 'A'L is Advanced Level.

Table III shows increasing enrollment of students into agriculture and time allocation which often generates conflict for time among subjects causing a disease called subjectivitis in curriculum development. Severe competition for timetable time \& resources throws out some subjects from schools claiming they are not important or are of low priority. Why agriculture to be thrown out?

The new subject approach embraces the teaching of a maximum of 20 subjects in a lower secondary school which must include general science or physics, chemistry and biology. Specified time is given on the timetable for the subjects chosen. A school can choose to offer 15 subjects out of 20 offered at lower secondary but must include stipulated subjects especially the science ones, language and mathematics needed to understand economic growth, technology generation and nation building.

There are successes in training of teachers at all levels, approved syllabuses, books for teaching are being sought, development partners are supportive, and piloting of innovative teaching is being done in some schools. Youth associations are registering support to the teaching.

TABLE III: ENROLLMENT, STAFFING AND TIME ALlOCATION/WEEK IN EDUCATIONAL INSTITUTIONS 2018

\begin{tabular}{|c|c|c|c|c|c|}
\hline LEVEL & ENROLLMENT & STAFF & TIME/WK & $\begin{array}{l}\text { WKS/TERM FOR } 3 \\
\text { TERMS }\end{array}$ & $\begin{array}{l}\text { WKS/SEMESTER FOR } 2 \\
\text { SEMESTERS }\end{array}$ \\
\hline PRIMARY & $+8,500,000$ & $+150,000$ & & 42 wks & - \\
\hline SECONDARY & $+1,200,000$ & $+20,000$ & $\begin{array}{l}80 \mathrm{~min}(\mathrm{~S} 1 \text { to } 2) \\
160 \mathrm{~min}(\mathrm{~S} 3 \text { to } 4) \\
360 \mathrm{~min}(\mathrm{~S} 5 \text { to6) }\end{array}$ & 42 wks & - \\
\hline TERTIARY & $+4,000$ & +200 & 12 to $16 \mathrm{hrs}$ & - & $34 \mathrm{wks}$ \\
\hline UNVERSITY & $+100,000$ & $+5,000$ & 17 to $20 \mathrm{hrs}$ & - & $34 \mathrm{wks}$ \\
\hline
\end{tabular}

Sources: These figures were supplied by Mulebeke [28] and Mulumba [29].

Bamberger and Cheema reported that research identifies factors which may sustain any programme and project to include: i). Leadership competence; ii). Effective collaboration; iii). Understanding the community; iv). Demonstrating programme impact; v). Strategic funding; vi). Staff involvement and integration; and vii). Programme responsiveness [30]. No doubt, teaching agriculture in schools must be seen to deliver. Impact on agricultural productivity, economic growth and technology development must be seen to emanate from that agriculture in schools and institutions. With so many priorities in the Ugandan economy, agriculture in schools and institutions may just fall by the way side and will be ignored if other investments can deliver better on employment, food security, income and family welfare to drive faster economic growth and development.

\section{CONCLUSIONS}

From history of education in Ugandan schools and pertinent literature, it is possible to draw some conclusions regarding happenings in efforts to offer agriculture in schools over the last 120 years in Uganda. These are some of the conclusions:

i. Some standards have been built over the last fifty years for teaching agriculture in schools.

ii. Policies and goodwill still exist to support the teaching of agriculture at various levels of education in Uganda.

iii. Policy reforms should not take us back or ignore a lot that has been achieved at various levels in schools. Curriculum adjustments need to strategize so as to help attain results demonstrated by USA and others in the developed world. The pursuit of our fellow African countries such as Kenya, Tanzania, South Africa and Nigeria in teaching school agriculture should really encourage us in Uganda to continue. 
iv. Attitudes and climate change constrain actual production but schools are doing what is possible to deal with them in creating awareness.

v. Strategic funding for investment in improving agriculture in schools is inadequate.

vi. Monitoring and evaluation of instruction by authorized agencies remains inadequate.

\section{RECOMMENDATIONS}

Based on the findings and conclusions the following recommendations are put forward:

i. Improve strategic funding to deliver better training facilities and capacity which will improve performance of learners for the expected impact on agricultural productivity in the country.

ii. Regular monitoring and evaluation of instruction will change attitudes and create data banks that will help mitigate the climate change effects.

iii. Policy reforms and curriculum development ought to be for real and based more on pertinent research findings to inform them so as to assure successful implementation that will deliver. The country should ensure laws are in place to enable more practical teaching and better capacity development of the future farmers of Uganda similar to the American program of the future farmers of America.

Faster economic growth and technology development emanating from agriculture in Uganda, through education and training, ought to deliver food security, more competitive export agricultural commodities, better incomes greater than the current per capita income of US dollars 700 and higher quality of life for the people.

\section{ACKNOWLEDGMENT}

Educational institutions in Uganda especially those that manage education and those that teach agriculture are greatly thanked for doing their work well, may their efforts be rewarded abundantly. Through their work the economy is bound to grow in leaps and bounds. Thanks to Dr. John James Okiror of Makerere University, Uganda and his research associates viz Hayward and Winterbottom of Cambridge and Oxford Universities (UK) for their investigations into the secondary school agriculture teaching policy in Uganda. Thanks to all my colleagues of Kyambogo University, Uganda and National Curriculum Development Centre, Uganda. Thanks to the farmers of Uganda and all those who have supported the teaching of agriculture in our schools such as Uganda Agricultural Business Council.

\section{REFERENCES}

[1] H. Binkley and C. Hammonds, EXPERIENCE PROGRAMS for learning Vocations in Agriculture, Danville, Illinois, USA: THE INTERSTATE Printers \& Publishers, Inc., 1970, pp 3-21, 604pp.

[2] World Almanac, Population projections by region, and for selected countries: 1995 to 2025, Nations, - Area and population, Washington DC, USA: The World Almanac, 1992, pp 300, 822.

[3] H. Hoeffler, E. Funch and I. Melchers I, Viable Farms: Naunced Assessment. Development and Cooperation $(D+C)$, International Journal, 46(6)250-251, 2014.

[4] World Almanac, Population projections by region, and for selected countries: 1995 to 2025 , Nations, - Area and population, Washington DC, USA: The World Almanac, 1992, pp 300, 822.

[5] Food Agriculture Organization, The state of food security and nutrition in the world 2019.

[6] Food and Agriculture Organisation, Policy Highlights Gender in Agricultural Development Policies: Agricultual Policy Support Service, Policy Assistance Division, FAO, Rome, Italy, TCAS Working Document 49 Gender Analysis in Macroeconomic and Agricultural Sector Policies and Programmes, 2006, 12pp.

[7] Inge.Gerremo, Senior Adviser SLU Global, Dr.Vet.Med. hc, Honorary Fellow Royal Swedish Academy of Agriculture and Forestry, previously responsible for agricultural issuses within Sida and issues related to the multilateral environment conventions. (2018 January 15). BUT, HOW ABOUT THE AFRICAN AGRICULTURE? Posted on January 15, 2018 By RUFORUM Communication Comment.

[8] World Bank, Uganda: Agriculture (A World Bank Survey), Washington DC, USA: A World Bank Publication, 1993, pp viii, 1$16,143-172$.

[9] J.D. Jameson, Agriculture in Uganda, London, UK: Oxford University Press, 1970, 305pp.

[10] J.K. Mukiibi (ed.), Agriculture in Uganda, Volume II, Crops, Kampala, Uganda: Fountain Publishers/CTA/NARO, 2001, 572pp.

[11] C. Dixon, Rural poverty; explanations and solutions. In Rural development in the Third World (Chapter 4), London, UK: Routledge, 1990, pp 50-61.

[12] M. Bamberger and S.Cheema, Case studies of project sustainability: Implications for policy and operations from Asian experience, Economic Institute for the World Bank, Washington D.C: The World Bank, 1990.

[13] B. Jordan, Developments in Agricultural Education in Ugandan, 1900-1963, Kampala, Uganda, Unpublished Ag.Ed research Study No.1: Faculty of Education, Makerere University, Kampala, 1990 $33 \mathrm{pp}$.

[14] R. Holliday, Practical skills and projects in agriculture for schools. Kampala, Uganda: Unpublished Agriculture Study Group, Makerere University Kampala, 1970.

[15] Uganda's Ministry of Education and Sports, Education for National Integration and Development, Report of Education Policy Review (EPRC), Kampala, Uganda: Marianum Press, 1989, 221pp.

[16] L.J. Phipps, Handbook on Agricultural Education in Public Schools, Danville, Illinois, USA: The Interstate \& Publishers, Inc.,1972, pp 575, 591, 599pp.

[17] S.O. Olaitan, Agricultural Education in the Tropics, London, UK: Macmillan Publishers, 1984, 194pp.

[18] R. Färe, S. Grosskopf and C.A.K. Lovell, Studies in productive analysis: The measurement of efficiency of production, Dordrecht, The Netherlands: Kluwer-Nijhoff Publishing, 1985, pp21-105, 165$198,216$.

[19] Uganda's Ministry of Education and Sports, Competency profile of a secondary school teacher in Uganda, Kampala, Uganda:Unpublished Report UNESCO Regional Office for Eastern Africa, Kampala Office, 2016a, $32 \mathrm{p}$.

[20] Uganda's Ministry of Education and Sports, Competency profile of a secondary school teacher in Uganda, Kampala, Uganda: Unpublished Report UNESCO Regional Office for Eastern Africa, Kampala Office, 2016b, $61 \mathrm{p}$.

[21] J.J. Okiror, G. Hayward and M.Winterbottom, Towards in-service training needs of secondary school agriculture teachers in a paradigm shift to outcome-based education in Uganda, pp 415-426 | Received 09 Dec 2016, Accepted 01 Jun 2017, Published online: 14 Jun 2017

[22] I.Mills, how to achieve Quality in Education, Bognor Regis, Great Britain: Anchor Publications, 1985 pp 12-30, 152 pp.

[23] W.F. Epeju, Primary Education and Agricultural Productivity in Kumi District of Eastern Uganda, Kampala, Uganda, Unpublished Research Report: Institute of Teacher Education (ITEK), 1996, 119 pp. 
[24] Uganda Bureau of Statistics, The National Population and Housing Census 2014, Main Report, Kampala, Uganda: The Republic of Uganda. 2016.

[25] C.B. Adupa and D.K. Mulindwa (eds), Institute of Teacher Education Kyambogo: Origin and Development, Kampala, Uganda: Monitor Publications, 1998, pp 61-100, 247pp.

[26] G. Mwanga-Waiswa, (2015). Achievements and Constraints in the Implementation of the National Agricultural Education Policy in Selected Institutions that offer Agriculture in Uganda, Kampala, Uganda, Unpublished Master of Education in Policy, Planning and Management 2015, Kyambogo University.

[27] M.M. Mulumba, Records National Curriculum Development Centre, 2019.

[28] R. Mulebeke, Personal communication, Head of Department, Agriculture, Kyambogo University, 2019.

[29] M.M. Mulumba, Personal communication, Specialist, Agricultural education, National Curriculum Development Centre, 2019.

[30] M. Bamberger and S. Cheema, Case studies of project sustainability: Implications for policy and operations from Asian experience, Economic Institute for the World Bank, Washington D.C: The World Bank, 1990.

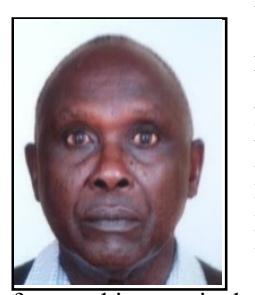

W. F. Epeju, Born in Uganda, 18th December 1947. Attended Primary School, Secondary School and University Education from 1954 for a period of 24 years with breaks for employment at different workplaces and at different appointment levels. Holds BSc Degree in Agriculture, Postgraduate Diploma in Education, Master of Science Degree in Agricultural Education, $\mathrm{PhD}$ in Agricultural Education. The key field of study is Agricultural Education and Extension for teaching agriculture in formal education and for training as well as advising farmers.

He has held a position in Livestock Improvement extension in beef ranching but has done much work in training teachers for teaching agriculture at various levels for the longest period worked hitherto. Has taught agriculture at the levels of Teaching Assistant, Assistant Lecturer through Lecturer, Senior Lecturer and Associate Professor. Has also been Head of Department, Deputy Director, Dean of Students and Faculty Dean at Kyambogo, Uganda. Has co-authored a book on Agriculture (Entebbe, Uganda, 512pp: The Government Printer, 1993) and also published several articles in several refereed journals. Currently teaches a research methods course to Graduate students at Kyambogo University and also supervises research of those graduate students who do research in agricultural education and extension. While working at Kyambogo University, has attended various workshops in Europe, Africa and Greece on agriculture.

Associate Professor Epeju PhD has been a member of some associations such as Uganda Society, Kyambogo Academic Staff Association, Commonwealth Association of Educational Administrators, Association of Third Studies, Kenya Chapter, and Regional Forum for African Universities that teach Agriculture. 